\title{
The Forgotten Shrines: General Masaharu Homma - General Tomoyuki Yamashita Execution Shrines Depicting History, Significance, and Deterioration as a Study for Heritage and Cultural Tourism Attraction Management and Development in Los Baños, Laguna
}

\author{
Jame Monren T. Mercado ${ }^{1}$ \\ ${ }^{1}$ Master of Arts in Cultural Heritage Studies Graduate Student, The Graduate School, University of \\ Santo Tomas, Manila, Philippines \\ ${ }^{1}$ College of Business Administration and Accountancy, Colegio de San Juan de Letran, Intramuros, \\ Manila, Philippines
}

\begin{abstract}
Shrines and monuments represent honourable respect for a person or a significant scenario that affects the cultural and heritage value of a community or a nation. These are also considered as a potential tourism resource of a community that could be used as a unique attraction for impending tourists. This paper identified and analyzed the practices of the community of Los Baños, Laguna, Philippines for the conservation and development of General Masaharu Homma - General Tomoyuki Yamashita Execution Shrines. The objectives of the study are: to identify the significances of the shrines and used it as a tourism development resource; to assess the practices of the authority on conservation and preservation; and to furnish recommendation that they could use for implementing or revising their plans and programs. It was recognized by the researcher that the sites were already deteriorated and mismanagement was already a problem. These things happened due to lack of financial capabilities and poor knowledge on conservation and preservation. As a general recommendation, the researcher suggested to create an organization attached to the local government unit of Los Baños that will supervise and develop heritage and cultural sites of the municipality.
\end{abstract}

\section{Introduction}

Cultural significance means the importance and value of any tangible and intangible heritage that reflects the past, practiced in the present and surpass to the future. Cultural significance is embodied in the place itself, its fabric, setting, use, associations, meanings, records, related places and related objects. [1] It is important to recognize and research the significances of cultural and heritage resources (tangible or intangible) to implement sustainable development which is to balance the 
efforts on conservation and tourism development. Places of cultural significance enrich people's lives, often providing a deep and inspirational sense of connection to community and landscape, to the past and to lived experiences. [2] Heritage and cultural development is not a waste of financial resource for a locality or the nation. Most of the heritage cities in the Philippines and other countries proved that heritage and cultural resource can be equated with economic and social community development such as the Taal Heritage Town in the Province of Batangas, Philippines [3], Pila Heritage Town in the Province of Laguna, Philippines [4], the UNESCO (United Nations Educational, Scientific and Cultural Organization) Heritage Cities of Melaka and George Town in Malaysia, [5] and the UNESCO World Heritage City of Vigan in the Province of Ilocos Sur, Philippines (which was recognized by the UNESCO as a model of best practices in World Heritage Site Management at the occasion of the $40^{\text {th }}$ anniversary of the World Heritage Convention) [6]. It all started with identifying one's own heritage and cultural resources, then researching about the significances and formulating plans, and projecting towards heritage conservation and development.

The science and nature city of Los Baños in the province of Laguna, Philippines is a first-class municipality, popular to the nearby urban cities because of its strategic location composed of both natural and cultural heritage sites and attractions. Some of it are as follows: the Mount Makiling National Park, the first declared national park in the Philippines; University of the Philippines-Los Baños Campus, the old Poblacion and the General Masaharu Homma - General Tomoyuki Yamashita Execution Shrines.

For this study, the researcher focused on researching about the historicity, significances and deteriorations of the Homma-Yamashita Execution Shrines that would eventually lead to planning and implementing the heritage and cultural attraction management of the municipality.

The shrines are commemorative markings for the two Japanese generals, Masaharu Homma and Tomoyuki Yamashita who were the commanders of the Japanese Imperial Army during World War II in the Philippines. The shrines are situated at the foot of Mount Makiling National Park in front of the Laguna de Bay. It is located at the Economic Garden, Barangay Timugan, Los Baños, Laguna, Philippines. The shrines are surrounded with rich forest vegetation, some local communities, and some national and local government offices. From Manila, it will take two hours of travel using a public transport bus or a private vehicle. Then from the National Highway of Los Baños, it will take a person to travel less than half a kilometer along the Magnetic Jamboree Road.

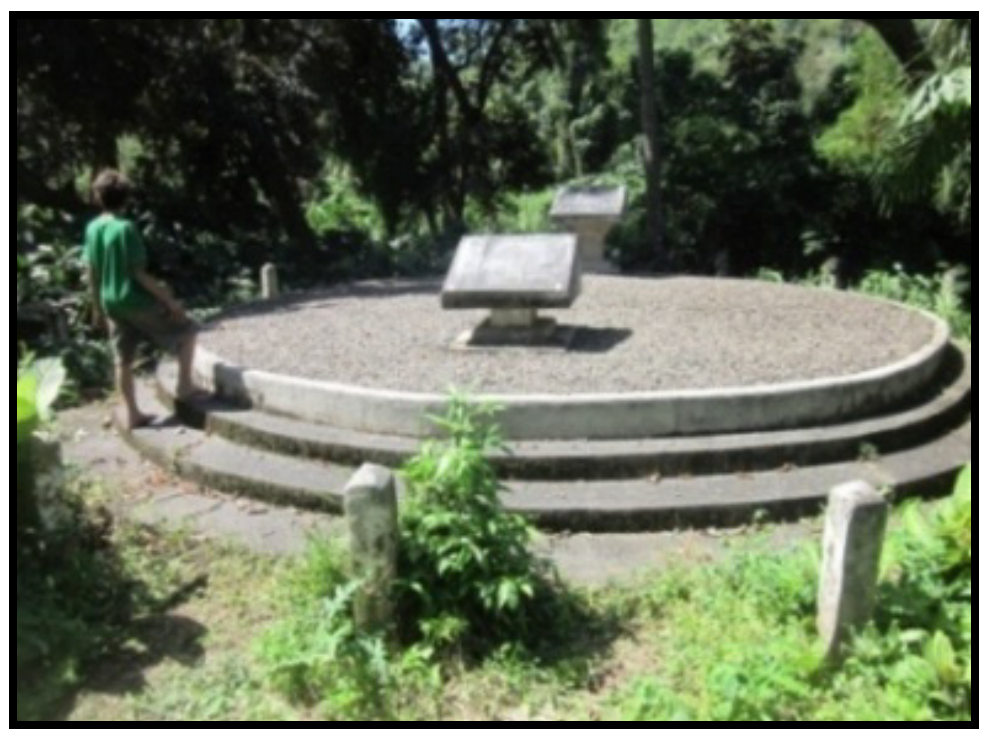

Figure 1. General Masaharu Homma Execution Shrine (photo taken by the researcher himself) 


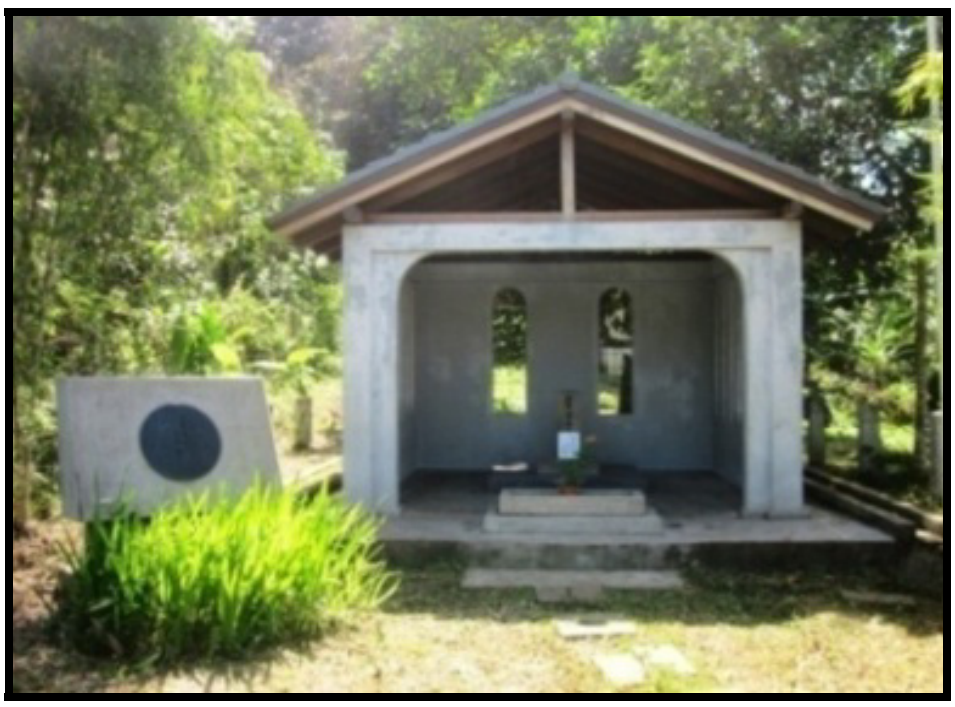

Figure 2. General Masaharu Tomoyuki Yamashita Shrine (photo taken by the researcher himself)

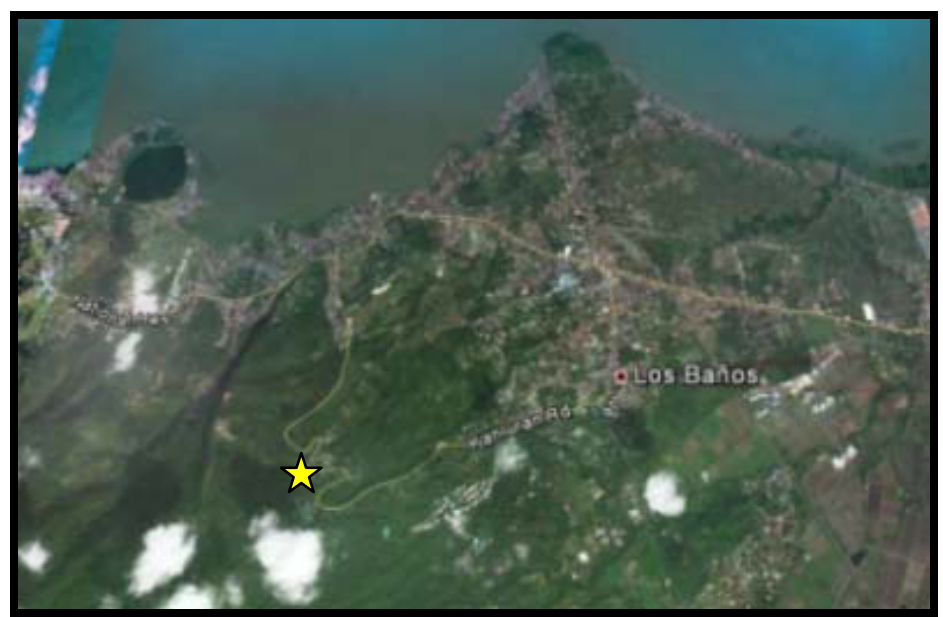

Figure 3. Google Earth satellite map of Los Baños Laguna indicating the location of the shrines (retrieved from Google Map. http://www.google.com.ph/maps)

\section{Methodology}

It is important to any heritage and cultural attraction development plan to recognize and to establish first a general framework that will lead to any plans and implementations of programs and projects. The researcher used the Burra Charter Process from the Burra Charter: The Australia ICOMOS (International Council of Monuments and Sites) Charter for Places of Cultural Significance 2013. The Burra Charter provides guidance for the conservation and management of places of cultural significance (cultural heritage places). [7] The cultural significance of a place and other issues affecting its future are best understood by a sequence of collecting and analyzing information before making decisions. Understanding cultural significance comes first, then development of policy and finally management of the place in accordance with the policy. [8]

This paper used the qualitative method of researching wherein data will be based on specific evidences: physical, oral, and documentary. Physical evidences were determined through existing photo documentation, landscape and setting analysis (identifying the importance of the environment 
that surrounded the shrine and its contribution to the visual catchment); damage assessment (deteriorations of the shrines), and SWOT (Strenghts, Weaknesses, Opportunities and Threats) analysis.

The oral evidences were based on interviews with current residents near the sites, World War II civilians, government officials (barangay level), and caretakers using self-made questionnaires and personal communication. Documentary or archival evidences revealed substantial information on the historicity, significance, and aesthetic unity of the place through library researches (National Library of the Philippines, Jose P. Laurel Memorial Foundation, University of Santo Tomas Miguel de Benavides Library), and internet information. The author gathered also some information from the practices and implemented projects of the UNESCO World Heritage City of Vigan in relation to conservation and sustainable development approaches. [9]

The researcher gathered all the information needed that described the shrines (as gleaned from the evidences), then constructed a statement of cultural significance, and identified the deteriorations and problems present (using the SWOT Analysis and Damage Assessment) that were eventually used to make recommendations on creating a management body and who will be in-charge of projects and programs for heritage and cultural conservation and tourism development.

\section{The Burra Charter Process}

Sequence of investigations, decisions and actions

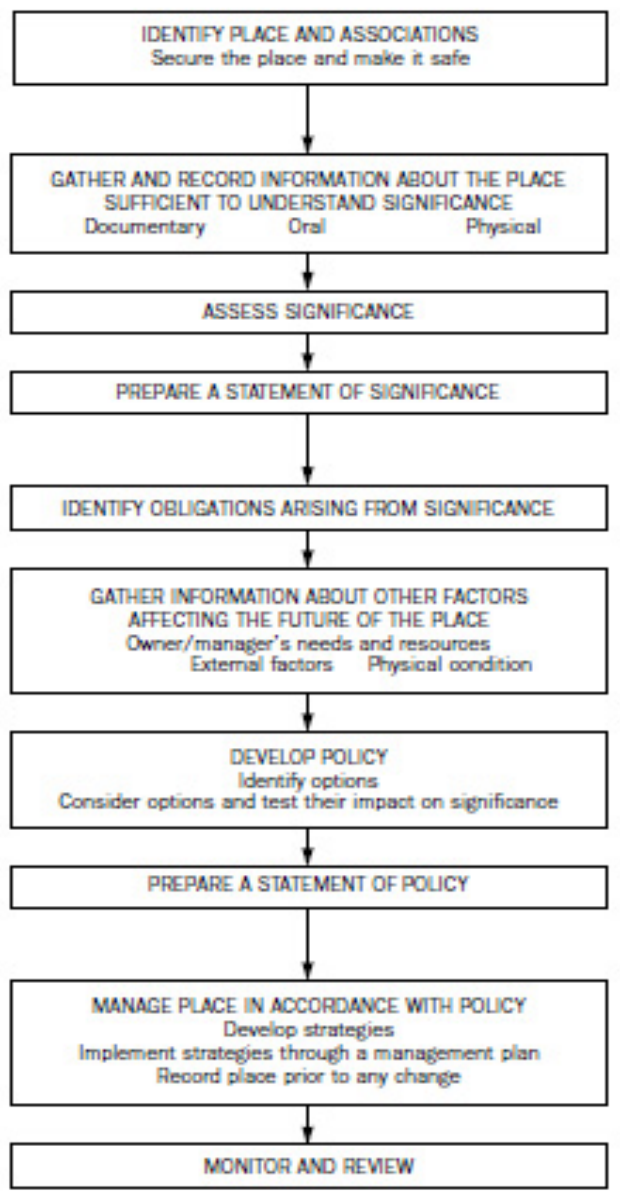

Figure 4. The Burra Charter Process (retrieved from The Burra Charter: The Australia ICOMOS Charter for Places of Cultural Significance, 2013) 


\section{Data analysis and discussion}

\subsection{Statement of Cultural Significance: Homma-Yamashita Execution Shrines}

The Homma-Yamashita Execution Shrines are some of the exemplary examples of Japanese memorial shrines located in the Philippines. It is also compared to some of the prominent shrines located at Japan, specifically the graves of General Tomoyuki Yamashita at Tamairein Cemetery, of General Masaharu Homma at the Yasukuni Memorial Shrine. They are both describe and distinguish Japanese art and aesthetic beauty in terms of their traditional graves. It also showcases their literature by having a marker engraved the last "haiku", a kind of Japanese poem, of General Yamashita.

The shrines are situated in the Municipality of Los Baños, Laguna, Philippines known as the "Special Science and Nature City of the Philippines" under the Presidential Proclamation No. 349, s. 2000, approved and signed by Former President Joseph Ejercito Estrada. [10] The place is included under the protected zone of Mount Makiling National Park which is considered to be a national forest reserve under the mandate of the national government. It is also part of the Los Baños Economic Garden which is for research regarding natural resources, businesses, agriculture, education, government and cultural heritage. [11]

The shrines have a vast historical background, from the Laguna of the Hispanic era up to the ground zero after World War II. It is considered to be part of the center for pathway migration of both Filipinos and Spaniards, from different provinces under the Southern Tagalog Region. It is also transformed into American camps during the colonization. Education also emerged in the area that was part of the University of the Philippines Los Baños - College of Agriculture, the first college founded by the institution in June 14, 1909. [12] During the Japanese occupation, it became part of the Los Baños Internment Camp or the Luzon Prisoner of War Camp, an area used for civilian captivation during World War II. [13]

The shrines are built to commemorate two of the greatest Japanese military generals during World War II, namely General Masaharu Homma, known to be as the "Beast of Bataan", leading the troops in the scandalous and tragic Death March of Bataan (wherein almost 10,000 American and Filipino soldiers suffered and died); and General Tomoyuki Yamashita, known to be the "Tiger of Malaya", leading the military operations in Singapore, Great Britain, the Malaya Region, and the Philippines.

The shrines are symbolically significant. The executions of Generals Masaharu Homma and Tomoyuki Yamashita signify a weak and poor judiciary during the Commonwealth era after World War II in the Philippines due to irregularities, irrelevancy, and inappropriateness of the testimonies and evidences presented to the court. Media and other historians at that time named it the "Kangaroo Court". [14] Their executions denote freedom and world peace because of the fact that they are considered one of the most influential and most barbaric Japanese military leaders. Unfortunately, it also signifies people's negligence regarding history, heritage conservation (because of a lot of deteriorations among the shrines), and cultural significance.

\subsection{Identifying Obligations Arising from the Cultural Significance}

SWOT Analysis is a planning tool used to understand the Strengths, Weaknesses, Opportunities, and Threats involved in a project or a business. SWOT involves specifying the objectives of the management plan and identifying the internal and external factors that are supportive of or unfavorable to the achievement of the objective. It is important to determine it for the progress of conservation management and development planning of the shrines, especially if it is being used as a tourism resource. Generally, the sites are identified as having a lot of strengths, especially in the interpretation and operations aspects. Caretakers were very accommodating to visitors and guests who visit the area, especially the Japanese guests. The caretakers maintain the cleanliness and orderliness of the shrines every time the shrines are not in good condition. 
The local government promotes the shrines to different travel blog sites that could encourage potential visitors. It is declared by the Philippine Department of Tourism as one of the historical destinations in Laguna. [15] The local government encourages their public and private school administrators to include the significance of the shrines in their lecture curriculum. The barangay sector (Barangay Timugan) is open for researchers who wish to study the shrines as part of their project for promotion. The barangay manages the area in cooperation with the Municipal Planning and Development Office for the maintenance and restoration aspects; and the Municipal Tourism Office for the marketing and promotions aspects.

But whenever there are strengths, there are also weaknesses that emerge. These must be classified accordingly and identified so as to deliver the proper solutions. Generally, these are: lack of monthly assessment of the shrines and lack of attention to details. The local government didn't have any coordination with the national level organizations (e.g.: National Historical Commission of the Philippines - NHCP) which are related to cultural heritage management.

The Homma execution shrine is privately owned thus, there are limits set to the plans being implemented and worse, the private owner became bankrupted and all his properties so as the shrines were confiscated by the bank. There is only one caretaker who is doing the entire task of maintaining the area. A caretaker doesn't have his own salary. They only depend on the donations given by the visitors. The local government needs professionals with vast knowledge regarding history and those who specialize on Japanese occupation in Los Baños, for information generation and records assembly.

The external environment of the shrines must also be examined and analyzed based on how the environment affects the shrines, regarding the conservation and development process. Identifying the environment based on the opportunities that could help the shrines and threats that could diminish not only its aesthetic unity but also its significance, authenticity, and integrity. These are the most outstanding results of the research: Opportunities - People knew about the importance of the shrines. Los Baños, Laguna is considered as a first-class municipality which denotes that its economic stability is higher than that of other municipalities.

The Los Baños municipal government could allot a distinct budget for the renovation, rehabilitation, and maintenance of the shrines. Different tourism-related private organizations and businesses joined together to create a body that would enhance and develop tourism-related plans and programs for the betterment of the municipal's economic stability (Los Baños Tourism Council).

Every year, private tourism institutions and the local government conduct the Los Baños Tourism Summit to identify potential tourism plans and to conduct seminars and workshops in relation to cultural heritage conservation and preservation. The area is part of the Mount Makiling National Park that is mandated by Republic Act 6967 or an Act to vest control, jurisdiction and administration of the forest reserve in Mount Makiling in the University of the Philippines, Los Baños, Laguna. [16]

Threats - Even though different tourism-based businesses promote the shrines, for their guests, their main goal is profitability rather than educating the people regarding cultural heritage significance. The shrines are within the Los Baños Economic Garden, where many establishments are situated. There is a need to resolve the waste disposal problem in the shrines. There are also squatters who surround the shrines.

The Mount Makiling Forest Reserve, near the shrines has animals and plants that contribute to the shrines' deterioration (e.g.: animal wastes and dried leaves/innumerable plants that would grow). The shrines are considered an open area so natural disasters (e.g.: typhoons and earthquakes) can destroy them. Some travel blog sites and other social networking sites publicized information regarding the shrines are inappropriate or false and such could lead to misunderstanding or misleading information. 


\subsection{Results from the Physical Deterioration Assessment}

Physical deterioration assessment is a process to know the components of the materials used in the construction, and if necessary, the previous preservation and restoration projects. It also identifies the physical deteriorations of the sites, the causes, and the solutions.

In the case of the shrines, deteriorations are classified into three distinct categories. Each has its basis for the process of deterioration and how it was started. These deteriorations are as follows:

a. Natural Deterioration Category - There are deteriorations brought out by a specific natural procedure and reactions such as vegetation of different plants and microorganisms like moss and forest grass; natural calamity like dry season, typhoons and earthquakes; and insect and animal infestation due to the environmental condition.

b. Human and Communal Intervention Category - Deteriorations that are the result of a personal or communal factor in activities and preferences. Activities of the people living near the vicinity and mismanagement of the shrines are considered to be the main causes of deterioration. Problems such as theft, lack of professional conservation method, lack of security and safety, waste disposal system, poor urban and rural planning, effects of commerce and industry; and personal needs and wants.

c. Chemical Reaction - These are deteriorations that resulted in a chemical composition changes to the materials by means of a natural or man-made actions. Rust, presence of hard water particles and discoloration are some of the problems of the shrines.

\section{Recommendation}

Due of the cultural significances of the shrines, it is definitely urgent that the government, of both the national and the local units, with the help of their constituents, must formulate constructive conservation, restoration, and tourism attraction plans and policies to develop and maintain the said shrines.

The following are the recommendations of the researcher:

a. Creating an organization attached to the local government of Los Baños, Laguna, responsible for conservation, preservation, and developing cultural heritage properties (Center for Los Baños Cultural Heritage and Conservation Management - CLBCHCM);

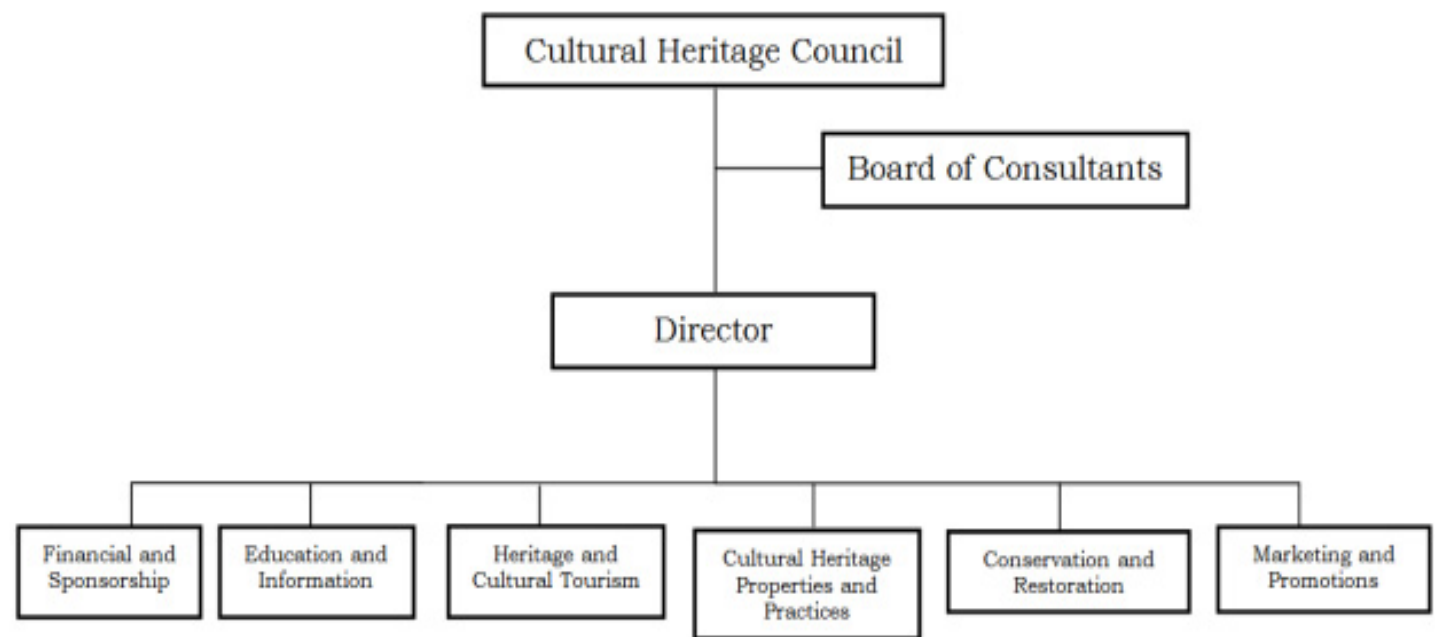

Figure 5. Proposed Organizational Chart for the CLBCHCM (made by the researcher himself) 
b. Budget planning for purchasing the shrines and take it over to the local cultural heritage organization (especially for the Homma Execution Shrine);

c. Proposal on making a comprehensive conservation planning and management (CPM), that will be composed of a conservation management plan (CMP), detailed engineering studies (DES), and feasibility study (FS); for the study of the shrines' physical, ethical, aesthetical, and social value;

d. Creation of a visitor management plan (VMP) that focuses on the rules and guidelines on tourism usage and visitation;

e. Proper documentation of the materials must be considered for further research;

f. Continuing the education of the local community about the importance of the shrines by means of integration in to the curriculum of the students (basic education, secondary and tertiary levels) as well as creating exhibitions located in strategic areas (tourism centers for example);

g. Incorporating the shrines in the marketing and promotions programs of the municipality, especially with regard to tourism (e.g.: adding these shrines as a tourism destination and making tour itineraries); and

h. Making further research about the area and having tie-ups with different institutions, for an expansive study of the shrines.

\section{Conclusion}

"Places of cultural significance reflect the diversity of our communities, telling us about who we are and the past that has formed us." [17] This is one of the contexts from the Australian ICOMOS Burra Charter Places/Objects of Significance 2013, identifying the essence of why one needs to conserve the cultural heritage of a community. Cultural heritage sites must be conserved and preserved to the fullest extent, because they represent the culture and historicity of the community. In accordance with the country's development, especially with regards to tourism, heritage conservation and preservation must be implemented but significance, authenticity, and the integrity of the place must be taken into consideration. Planning and developing heritage and cultural tourism attractions must be based on the statement of significance rather than on the high selling point of tourism activities in a locality. Proposed conservation and tourism plans and projects for the municipality of Los Baños must be considered by the government and be implemented properly, with the help of a partner institution.

\section{References}

1. Australia ICOMOS, Burra Charter (2013)

2. Ibidem

3. L.A. Aguda, M.A. Tamayo, L. Barlan, Effects of Heritage Tourism to the Municipality of Taal, Batangas, Philippines, Educ. Res. Int'1., 2, 91-95 (2013)

4. M. Cinco, (2011). "Heritage Village" to rise in Laguna. Inquirer.net. Retrieved from http://newsinfo.inquirer.net/inquirerheadlines/regions/view/20110513-336342/Heritage-village-torise-in-Laguna

5. UNESCO World Heritage Centre, Melaka and George Town, Historic Cities of the Straits of Malacca. UNESCO World Heritage Convention. Retrieved from http://whc.unesco.org/en/list/1223

6. City Government of Vigan, (2013). The Historic Town of Vigan World Heritage Site. UNESCO World Heritage Convention. Retrieved from http://whc.unesco.org/en/news/948/

7. Australia ICOMOS, ibidem

8. Ibidem

9. City Government of Vigan, ibidem 
10. Official Gazette of the Republic of the Philippines, Proclamation Order No. 349 s. 2000 (2000)

11.D. Shavit, The United States in Asia: A Historical Dictionary (Greenwood Published Group Inc, Connecticut, 1990)

12. University of the Philippines Los Baños, UPLB: 100 Years in the Science and Nature City (2008)

13.ibidem

14.A. Kenworthy, The Tiger of Malaya (Exposition Press, New York, 1953)

15. P. So, The First Philippine Domestic Travel Tour Handbook 2008 (PTAA, 2008)

16. Forestry and Natural Resource, Forestry and Natural Resources (UPLB, 2012)

17. Australia ICOMOS, ibidem 